\title{
Species composition and diversity of mangrove swamp forest in southern Nigeria
}

\begin{abstract}
The study was conducted to assess the species composition and diversity of Anantigha Mangrove Swamp Forest in southern Nigeria. Systematic line transect technique was adopted for the study. From the total mangrove area of 47.5312 ha, four rectangular plots of 10 by $1000 \mathrm{~m}$ representing sampling intensity of 8.42 percent were demarcated. Total identification and inventory was conducted and data on plant species name, family and number of stands were collected and used to compute the species importance value and family importance values. Simpson's diversity index and richness as well as ShannonWeiner index and evenness were used to assess the species diversity and richness of the forest. Results revealed that the forest was characterized by few families represented by few species dominated by Rhizophora racemosa, Nypa fructicans, Avicennia germinans and Acrostichum aureum which were also most important in the study and a few other species. Furthermore, presence of Nypa palm (Nypa fructicans) as the second most abundant species in the study area was indicative of the adverse effect of human activities on the ecosystem. The Simpson's diversity index and richness of 0.83 and 5.896, and ShannonWeiner diversity and evenness of 2.054 and 0.801 respectively were low, compared to mangrove forests in similar locations thus, making these species prone to extinction and further colonization of Nypa fructicans in the forest. Therefore, it was recommended that enrichment planting be carried out in the mangrove forest using indigenous species to improve the species richness status of the area, deliberate attempt should be undertaken to reduce the abundance of Nypa palm in the area, enlightenment campaigns be conducted to sensitize the local population on the effect of unsustainable management and utilization of mangrove forest and forest resources.
\end{abstract}

Keywords: mangrove, diversity, extinction, human activities, indigenous species
Volume 3 Issue 2 - 2018

\author{
Sijeh Agbor Asuk, Eric Etim Offiong , Nzube \\ Michael Ifebueme, Emediong Okokon Akpaso \\ University of Calabar, Nigeria
}

Correspondence: Sijeh Agbor Asuk, Department of Forestry and Wildlife Resources Management, University of Calabar, PMB I I 5, Calabar, Nigeria, Email sijehasuk@gmail.com

Received: October 23, 2017 | Published: April 13, 2018

\section{Introduction}

Tropical and subtropical ecosystems support most of the vegetation types of the world. ${ }^{1-5}$ Within the different vegetation types Mangroves are large, extensive and salt-tolerant types of trees up to medium height and shrubs that grow in saline coastal sediment habitats in the tropical and subtropical intertidal regions of the world (such as bays, estuaries, lagoons and creeks) mainly between latitudes $25^{\circ} \mathrm{N}$ and $25^{\circ} \mathrm{S}$. The remaining mangrove forest areas of the world in 2000 was 53,190 square miles $\left(137,760 \mathrm{~km}^{2}\right)$ spanning 118 countries and territories. ${ }^{6}$

Nigeria has West Africa's largest concentration of mangrove echo zone and the third most extensive mangrove ecosystems in the world after India and Indonesia. ${ }^{7-10}$ The area of the mangrove ecosystem, which comprises of about $35 \%$ of the total cover for West Africa, ${ }^{11}$ spans between 997,000 ha to 105,339 ha of which 480,000 ha is planted. ${ }^{9,10}$ According to United States Agency for International Development (USAID), ${ }^{12}$ mangrove swamps in Nigeria are found in nine of the thirty six states stretching along the entire coast, and are either partially or totally flooded throughout the year with plant community that survive in marine and brackish habitats, replaced further inland by freshwater swamp forests. The Niger Delta covers between the region of Benin River in the west and the Calabar, Rio del Rey estuary in the west, harbours one of the world's largest contiguous block of mangrove forest characterized by rich biodiversity, highly diverse and productive ecosystems, good agricultural land and excellent fisheries. ${ }^{8,13,14}$
Tomlinson, ${ }^{15}$ Omogoriola et al. ${ }^{13}$ and UNEP-WCMC ${ }^{16}$ reported that eight true West African mangrove species including Avicennia germinans, Rhizophora mangle, Rhizophora racemosa, Rhizophora harrisonii, Laguncularia racemosa, Conocarpus erectus, Nypa fruticans and Acrostichum aureum were found in Nigeria especially in the Niger Delta region. They added that the most predominant plant species were those in families Rhizoporacea, Avicenniaceae and Combretaceae such as Rhizophora racemosa, Rhizophora harrisonii, Rhizophora mangle, Avicennia africana (White mangrove), Laguncularia racemosa, Conocarpus erectus and a few other stunted shrubs and woody species, ${ }^{12,17-19}$ providing highly productive habitat and ecological niche for reptiles, monkeys, birds, fishes, shrimps, mollusks, and other wildlife species as well as a number of other ecological services. ${ }^{20}$

The mangrove ecosystem is confronted by diverse threats, resulting from the dependence of rural communities around the Niger Delta on the forest resource as major source of livelihood. These threats include population growth, extensive clearing of the forest for fuel wood, agriculture, to permit the construction of navigational canals, villages, extraction of a number of non-timber forest products for craft, oil exploration, deforestation and commercial fish farming. ${ }^{13,14,21,22}$ According to Okpiliya et al. ${ }^{20}$ when the mangrove forest is removed it is replaced by invasive species such as Nypa fruticans (Nipa palm), a fast colonizing exotic plant species that does not provide the extensive ecological services provided by native mangroves. He added that the threats to these forests are increasing, and the protective measures in place are sorely inadequate. These informed the need for thorough 
and constant evaluation of the resource status of the mangrove forest to ensure the propagation, preservation and sustainable utilization of its resources for posterity. Thus, the objectives of the study sought assessment the plant species composition by families, the diversity index, and the species and family importance values in the study areas.

\section{Materials and methods}

\section{Study area}

The study was carried out in the Mangrove Swamp Forest of Anantigha in Calabar South Local Government Area (LGA), Cross River State, Nigeria (Figure 1), bounded to the North-East by Calabar, to the West by Odukpani Local Government Areas and South-East by Akpabuyo Local Government Area. The study area which lies between latitude 4 54 '22" and 4 54 '57' North and longitude 8 18 ' $47^{\prime \prime}$ and $8^{\circ} 19^{\prime} 15^{\prime \prime}$ East is located along the Nigeria-Cameroon coast and forms part of the Calabar mangrove estuary under West African mangrove sub-formation. ${ }^{18}$ The forest covers an area of 47.5312 ha and is flanked on its eastern and western borders by the Great Kwa and Calabar River respectively and to the south, by the Atlantic Ocean. The area is characterized by a tropical humid climate with highest rainfall of $1,880 \mathrm{~mm}$ between July and September and lowest rainfall of $240 \mathrm{~mm}$ between December and February. The temperature of the area ranges from maximum of $30^{\circ} \mathrm{C}$ to minimum of $23^{\circ} \mathrm{C}$ with high relative humidity usually between $80 \%$ and $100 \%$, high salinity of $3.8 \%$ in the dry season and $0.5 \%$ in the rainy season and the soils are sandy, light hued in some location, but clayey, muddy, dark grey in colour, water logged and boggy. ${ }^{18}$

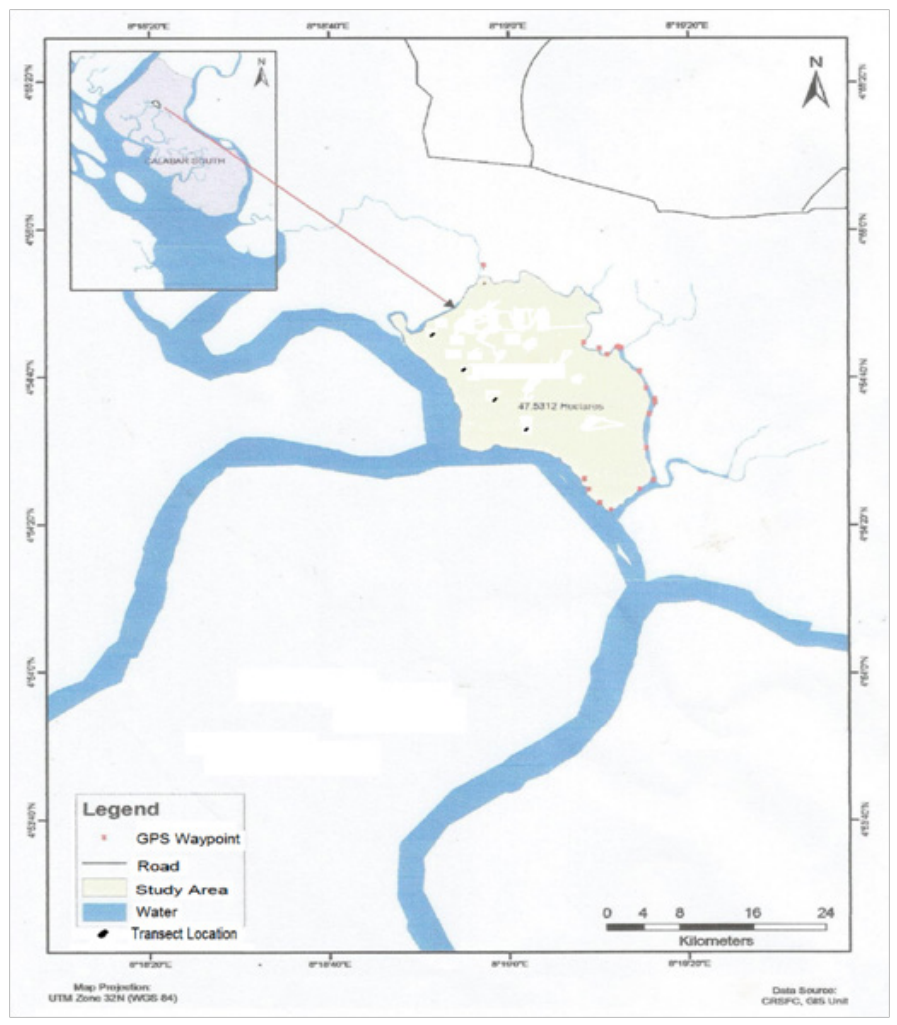

Figure 1 Map showing location of Anantigha mangrove swamp forest.

The predominant vegetation type is mangrove with flora consists of trees and shrubs of few genera of varying species. The common genus is Rhizophora with three species; $R$. racemosa, $R$. harisonii and $R$. mangle characterized by stilt roots. Other species included Avicennia africana, Lagunculeria racemosa, palms, Prodococcus bateri, Ancistrophyllum opacum and the gregarious and aggressive Nypa fruticans. ${ }^{17,18}$

\section{Data collection}

Reconnaissance survey of the area was conducted with a Global Positioning System (GPS) and the map was produced at the Cartography and Mapping Unit of the Cross River State Forestry Commission. The produced map was used to plan actual data collection. Systematic line transects technique, modified from Dunn et al. ${ }^{23}$ with sampling intensity of $8.42 \%$ was adopted for the study. Due to the sparse vegetation in the study area, four transects of $1,000 \mathrm{~m}$ length and $10 \mathrm{~m}$ width were established in a North-east direction at $2,000 \mathrm{~m}$ interval and plants with $6 \mathrm{~cm}$ girth and above were identification and enumerated $5 \mathrm{~m}$ on both sides of the transect line. ${ }^{23}$ Data on species name and species family were collected to determine the composition, richness and diversity of plant species in the area (Figure 1).

\section{Data analysis}

The frequency, density, species importance value (SIV) as well as family importance values (FIV) were computed for all species and families as adopted by Agbagwu et al. ${ }^{21}$ and Razavi et al. ${ }^{24}$ SIV and FIV were calculated as shown below:

$$
S I V=\text { relative frequency }+ \text { relative density }+ \text { relative dominance }
$$

$$
\begin{aligned}
& \text { Relative frequency }=\frac{\text { Noof plots containing a species }}{\text { Sumof frequencies of all species }} \times 100 \\
& \text { Relative density }=\frac{\text { Noof individuals of a species }}{\text { Total No.of individuals of all species }} \times 100 \\
& F I V=\text { relativedensity }+ \text { relative diversity }+ \text { relativedominance } \\
& F I V=\text { relative density }+ \text { relative diversity }+ \text { relativedominance }
\end{aligned}
$$

$$
\text { Relativedensity }=\frac{\text { No.of individuals of the family }}{\text { Total No.of individuals in the sample }} \times 100
$$$$
\text { Relative diversity }=\frac{\text { Noof species in the family }}{\text { Total No.of species in the sample }} \times 100
$$

$$
\text { Relative dominance }=\frac{\text { Basal area of the family }}{\text { Total basal area in the sample }} \times 100
$$

For the sake of this study relative dominance was not used in the computation of SIV and FIV because basal area of some plants could not be determined for computation of relative dominance. This was also adopted by Razavi et al. ${ }^{24}$

The species diversity and richness of the forest were calculated using Simpson's and Shannon Wiener diversity index. ${ }^{25,26}$ Simpson's index is given as: 


$$
D=\sum_{i=1}^{q} \frac{n i(n i-1)}{N(N-1)}
$$

Simpson's diversityindex $(I)=1-D$

$$
\text { Simpson's richness }=D^{-1}
$$

Where, $D=$ Simpson's index value, $N=$ total number of individual trees enumerated, $n_{i}=$ total number of species $i$ enumerated; $i=1, \mathrm{n}, q$ $=$ number of different species enumerated.

Shannon-wiener diversity index, $H$, was estimated using the equations below.

$$
\begin{aligned}
& H=\sum_{i=1}^{s}\left[P_{i} \times \operatorname{In}\left(P_{i}\right)\right] \\
& \text { Evenness }(E)=H / \text { Hmax } \\
& H \operatorname{Hax}=\operatorname{In}(S)
\end{aligned}
$$

Where, $P_{i}$ is the proportion of total sample represented by species $i$ divided by total number of sample

$S$ is the number of species present or species richness, $\mathrm{H}_{\max }$ is the maximum diversity possible or richness.

\section{Results}

Results from the study were computed, analyzed, interpreted are presented in the Tables below:

\section{Floristic composition of the study area}

The floristic composition of plants and family distribution in the area are shown in the Table $1 \& 2$. The results in Table 1 indicated that 13 plant species in 11 families were encountered in the study area. The plant population was represented by the following species Rhizophora racemosa, Nypa fructicans, Avicennia germinans, Acrostichum aureum, Drepanocarpus lanatus, Lagunicularia racemosa, Hibiscus tiliaceus, Thespesia populnea, Pandanus candelabrum, Carapa procera, Raphia hookeri, Conocarpus erectus and Chrysobalnus spp. The most abundant species in the area were Rhizophora racemosa, Nypa fructicans, Avicennia germinans and Acrostichum aureum. While Rhizophora racemosa had the highest SIV value followed by Nypa fructicans. From Table 2, it was observed that there were 11 families in the area including Rhizophoraceae, Arecaceae, Malvaceae, Combretaceae, Avicenniaceae, Pteridaceae, Fabaceae, Pandanaceae, Meliaceae, Palmaceae and Chrysobalanaceae. All the families except Malvaceae, Combretaceae, had single species. Dominant families were Rhizophoraceae, Arecaceae, Acanthaceae, Pteridaceae, Fabaceae, Pandanaceae, Meliaceae, Palmaceae and Chrysobalanaceae. Rhizophoraceae had highest FIV of 39.88 while Acecaceae and Malvaceae had values of 24.15 and 7.69.

Table I Species density, relative density, relative frequency and species importance value (SIV) of plants found in Anantigha Mangrove Swamp forest

\begin{tabular}{lllll}
\hline S/N & Plant Species & Families & $\begin{array}{l}\text { Species Density } \\
\text { (Individuals/ Ha) }\end{array}$ & Siv \\
\hline I & Rhizophora Racemosa & Rhizophoraceae & 45 & 34.892 \\
2 & Nypa Fructicans & Arecaceae & 23 & 19.245 \\
3 & Avicennia Germinans & Avicenniaceae & 18 & 15.468 \\
4 & Acrostichum Aureum & Pteridaceae & 15 & 13.309 \\
5 & Drepanocarpus Lanatus & Fabaceae & 10 & 9.892 \\
6 & Lagunicularia Racemosa & Combretaceae & 8 & 8.273 \\
7 & Hibiscus Tiliaceus & Malvaceae & 7 & 8.094 \\
8 & Thespesia Populnea & Malvaceae & 5 & 6.295 \\
9 & Pandanus Candelabrum & Pandanaceae & 4 & 5.935 \\
10 & Carapa Procera & Meliaceae & 3 & 3.957 \\
11 & Raphia Hookeri & Palmaceae & 2 & 3.777 \\
12 & Conocarpus Erectus & Combretaceae & I & 1.799 \\
13 & Chrysobalnus Spp & Chrysobalanaceae & I & 1.439 \\
\hline
\end{tabular}

Table 2 Family density, relative density, relative frequency and family importance value (FIV) of plants found in Anantigha Mangrove Swamp forest

\begin{tabular}{lllll}
\hline S/N & Family Name & $\begin{array}{l}\text { Number Of Species Within } \\
\text { Family }\end{array}$ & Density (Individuals/ Ha) & Fiv \\
\hline I & Rhizophoraceae & I & 45 & 39.88 \\
2 & Arecaceae & 1 & 23 & 24.15 \\
3 & Malvaceae & 2 & 12 & 24.06 \\
4 & Combretaceae & 2 & 8 & 21.17 \\
5 & Avicenniaceae & $\mathrm{I}$ & 18 & 20.35 \\
6 & Pteridaceae & 1 & 15 & 18.18 \\
7 & Fabaceae & $\mathrm{I}$ & 10 & 14.74 \\
\hline
\end{tabular}




\begin{tabular}{|c|c|c|c|c|}
\hline $\mathbf{S} / \mathbf{N}$ & Family Name & $\begin{array}{l}\text { Number Of Species Within } \\
\text { Family }\end{array}$ & Density (Individuals/ Ha) & Fiv \\
\hline 8 & Pandanaceae & I & 4 & 10.77 \\
\hline 9 & Meliaceae & I & 3 & 9.5 \\
\hline 10 & Palmaceae & I & 2 & 9.32 \\
\hline II & Chrysobalanaceae & I & I & 7.87 \\
\hline
\end{tabular}

\section{Species diversity of the study}

The indices used to assess the species diversity of the study area are shown in Table 3. The results from Table 3 revealed that the sampled area had a total of 13 species with 553 individuals. The Simpson's and Shannon-Weiner diversity index values for the forest were 0.830 and 2.054 respectively while values for Simpson's richness, ShannonWeiner richness and Shannon-Weiner evenness were 5.896, 2.565 and 0.801 respectively. Of the 13 species found in the entire sampled forest area, 11 with 114 individuals, 12 with 122 individuals, 10 with 175 individuals and 12 with 139 individuals species were found in $\mathrm{T}_{1}$,
$\mathrm{T}_{2}, \mathrm{~T}_{3}$ and $\mathrm{T}_{4}$ correspondingly. Highest values for the various diversity indices were observed in $T_{2}$ followed by $T_{1}, T_{4}$ and $T_{3}$ except for evenness that was highest in $\mathrm{T}_{1}$ followed by $\mathrm{T}_{2}, \mathrm{~T}_{4}$ and $\mathrm{T}_{3}$.

\section{Common features in the area}

The state of mangrove forest close to community settlement is shown in Figure 2. He stacks of firewood and presence of canoes in Figure 2 indicated the presence of firewood collection and fishing activity in the area. It also revealed that Nypa fructicans had seriously encroached reasonable portions of the river banks in areas close to the community settlement.

Table 3 Diversity indices used to assess the population

\begin{tabular}{llllll}
\hline Diversity indices & T1 & T2 & T3 & T4 & Entire sample area \\
\hline Baseline GPS coordinates & $\begin{array}{l}4^{\circ} 54^{\prime} 442^{\prime \prime} \mathrm{N} \\
8^{\circ} 18^{\prime} 509 \mathrm{E}\end{array}$ & $\begin{array}{l}4^{\circ} 54^{\prime}, 418^{\prime \prime} \mathrm{N} \\
8^{\circ} 18^{\prime} 541 \mathrm{E}\end{array}$ & $\begin{array}{l}4^{\circ} 54^{\prime} 389^{\prime \prime} \mathrm{N} \\
8^{\circ} 18^{\prime} 580 \mathrm{E}\end{array}$ & $\begin{array}{l}4^{\circ} 54^{\prime} 217^{\prime \prime} \mathrm{N} \\
8^{\circ} 18^{\prime} 034 \mathrm{E}\end{array}$ & \\
Number of plant species present $(S)$ & 11 & 12 & 10 & 12 & 13 \\
Total No of stands $(N)$ & 114 & 122 & 175 & 139 & 553 \\
Simpson's diversity index $(I)$ & 0.857 & 0.863 & 0.704 & 0.840 & 0.830 \\
Simpson's richness & 7.001 & 7.293 & 3.373 & 6.265 & 5.896 \\
Shannon-Weiner diversity Index $(H)$ & 2.097 & 2.120 & 1.611 & 2.060 & 2.054 \\
Shannon-Weiner richness $(\operatorname{Hmax})$ & 2.398 & 2.485 & 2.303 & 2.485 & 2.565 \\
Shannon-Weiner evenness $(E)$ & 0.875 & 0.853 & 0.700 & 0.829 & 0.801 \\
\hline
\end{tabular}

Note: $T_{1}, T_{2}, T_{3}$ and $T_{4}$ represents transects I, 2, 3 and 4

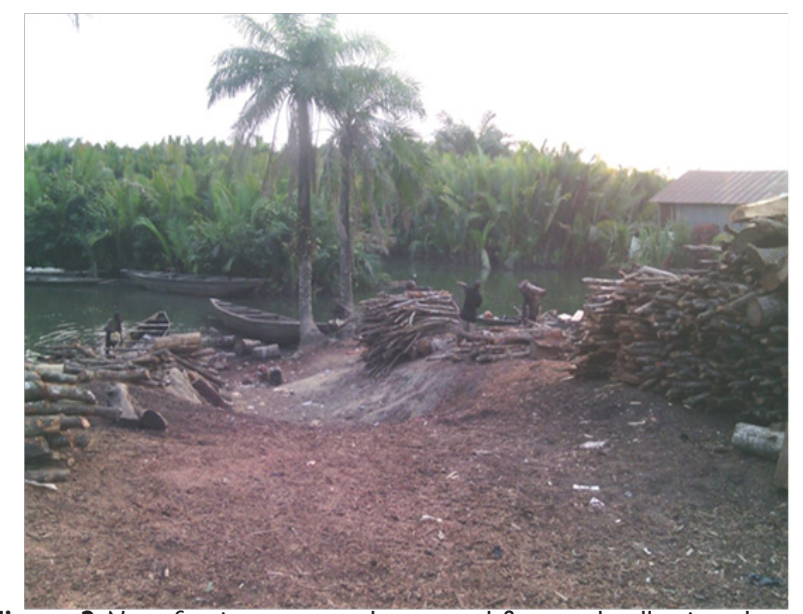

Figure 2 Nypa fructicans encroachment and firewood collection along river banks.

\section{Discussion}

The results in Table $2 \& 3$ indicated that the mangrove forest was predominated by Rhizophora racemosa, Nypa fructicans, Avicennia germinans and Acrostichum aureum with Rhizophora racemosa as the most dominant with highest SIV and Rhizophoraceae having the highest number of individual species and FIV. According to Ukpong, ${ }^{18}$ USAID $^{12}$ and Ogar et al in 2016, the family Rhizophoraceae, especially Rhizophora racemosa, was the most predominant species found in mangrove forests around the Niger Delta. In addition, six out of the eight true mangrove species found in Nigeria as well as the Niger Delta existed in the study area thus, confirming findings of Tomlinson, ${ }^{15}$ Ukpong, ${ }^{18}$ UNEP-WCMC,${ }^{16}$ USAID, ${ }^{12}$ Omogoriola et al. ${ }^{13}$ and Ogar et al. ${ }^{19}$

The presence as well as the position of the gregarious, aggressive and invasive, Nypa fructicans, as second most abundant species in the forest indicated that the mangrove ecosystem was seriously disturbed and at risk of losing most of its plant species in the coming future. In 
a study by Olowokudejo et al. ${ }^{14}$ on the floral diversity of the littoral vegetation of Southeastern Nigeria, there was a strong presence of Nypa fructicans. They reported that human activities in the area, including areas around the cross river, provide favourable opportunity for the invasion of Nypa which subsequently gains advantage over other species and then displaces the mangrove. The area had been decimated by the aggression of this invasive species due to its superficial fibrous root system which lacks the holding ability to maintain coastline integrity or offer the extensive ecological services provided by native mangroves. ${ }^{20}$ Some of the activities identified to be responsible were population growth, clearing for firewood and agriculture and unsustainable extraction of NTFPs for food and local craft and commercial fishing. ${ }^{13,14,21,22}$ As seen in Figure 2, areas close to community settlement were faced with some of these challenges such as collection of firewood collection, fishing and encroachment of the river banks with Nypa. From the result obtained in Table 3, values from the diversity indices obtained for this study were low compared to another study conducted in Akpabuyo mangrove, with exceptionally high Shannon index of 4.65 and evenness of 0.97 and Simpson's diversity, Shannon-Weiner index and Margalef values of $0.99,4.6$ and 21.67 respectively reported for another study in the mangrove forest around the coastal zones of Akwa Ibom and Cross River State, Nigeria. ${ }^{14}$ The low species diversity in the study area was attributed to the level of forest resource utilization. Also as reported by Olowokudejo et al., ${ }^{14}$ due to climate change, the mangrove forests in this zone has experienced increased coastal flooding as well as tidal fluctuations from the Atlantic Ocean which has greatly influenced the mangrove ecosystem negatively.

The species diversity between transects were compared because it is largely accepted that the environmental heterogeneity of an area significantly affects it species diversity. ${ }^{27-29}$ Number of plant species (S) and total number of stands $(\mathrm{N})$ in $\mathrm{T}_{1}$ to $\mathrm{T}_{2}$ were $11,12,10,12$ and $114,122,175$ and 139 respectively. Highest values of Simpson's and Shannon-Weiner diversity index were observed in $\mathrm{T}_{2}$ followed by $\mathrm{T}_{1}$, $\mathrm{T}_{4}$ and $\mathrm{T}_{3}$ indicating that among transects, $\mathrm{T}_{2}$ was the most diverse and $\mathrm{T}_{3}$ was the least diverse in terms of species composition. Similarly pattern were seen for Simpson's and Shannon-Weiner richness with $\mathrm{T}_{2}$ as the most species rich transect and $\mathrm{T}_{3}$ and least species rich transect. But in terms of evenness, $T_{1}$ most even transect followed by $T_{2}, T_{4}$ and $T_{3}$. The results on species richness suggested that there were few plant species represented by few families and many of the species had very few individual stands thus making them prone to extinction. ${ }^{14}$ According to Condit et al. ${ }^{30}$ species richness is positively associated with species abundance suggesting that large population of plant species is less prone to extinction than small ones. This is because in the species abundance-species diversity relationship, a habitat supporting large numbers of individuals can support more populations and more species than habitat supporting small number of individuals.

\section{Conclusion and recommendations}

The mangrove forest of Anatigha was composed of the major species that classifies it a mangrove forest area. The forest was characterized by few families represented by few species dominated by Rhizophora racemosa, Nypa fructicans, Avicennia germinans and Acrostichum aureum which were also the most important in the study and a few other species including Drepanocarpus lanatus, Lagunicularia racemosa, Hibiscus tiliaceus, Thespesia populnea, Pandanus candelabrum, Carapa procera, Raphia hookeri,
Conocarpus erectus and Chrysobalnus spp. The presence of Nypa palm (Nypa fructicans) as the second most abundant species in the study area was indicative of the adverse effect of human activities, such as clearing the forest for firewood collection, agriculture and fishing activities, on the ecosystem. The species diversity, richness and evenness of the forest were low compared to mangrove forests in similar locations thus, making these species prone to extinction and further encouraging the spread of Nypa palm (Nypa fructicans) in the forest. It was therefore recommended that enrichment planting be carried out in the mangrove forest using species indigenous to the area to improve the species richness of the area. There should be a deliberate attempt to reduce the abundance of Nypa palm in the forest. Enlightenment campaigns should be conducted to sensitize the local population on the effect of unsustainable removal of the mangrove vegetation as well as on the sustainable management and utilization of the forest and forest resources.

\section{Acknowledgements}

None.

\section{Conflict of interest}

Authors declare that there is no conflict of interest.

\section{References}

1. Upadhyay VP, Ranjan R, Singh JS. Human-mangrove conflicts: The way out. Current Science. 2002;83(11):1328-1336.

2. Swamy SL, Dutt CBS, Murthy MSR, et al. Floristics and Dry matter dynamics of Tropical Wet Evergreen Forests of Western Ghats, India. Current Science. 2010;99(3):353-364.

3. Jhariya MK, Bargali SS, Swamy SL, et al. Impact of forest fire on biomass and Carbon storage pattern of Tropical Deciduous Forests in Bhoramdeo Wildlife Sanctuary, Chhattisgarh. International Journal of Ecology and Environmental Science. 2014;40(1):57-74

4. Kittur B, Swamy SL, Bargali SS. Wild land Fires and Moist Deciduous Forests of Chhattisgarh, India: Divergent Component Assessment. Journal of Forestry Research. 2014;25(4):857-866.

5. Behera SK, Sahu N, Mishra AK, et al. Aboveground biomass and carbon stock assessment in Indian tropical deciduous forest and relationship with stand structural attributes. Ecological Engineering. 2017;(99):513524.

6. Giri C, Ochieng E, Loveland T, et al. Status and distribution of mangrove forests of the world using earth observation satellite data. Global Ecology and Biogeography. 2011;(20):154-159.

7. Macintosh DJ, Ashton EC. Report on the Africa Regional Workshop on the sustainable management of mangrove forest ecosystems. ISME/ cenTER/CAW; 2003

8. Spalding M, Kainumu M, Collins L. London: World Atlas of Mangroves, Earthscan; 2010

9. Federal Ministry of Environment (FME). Readiness Preparation Proposal (R-PP). Forest Carbon Partnership Facility (FCPF); 2013.

10. FAO. Global forest resources assessment 2015: desk reference. Rome: Food and Agriculture Organization of the United Nations; 2015:64-69.

11. NEP-WCMC. Spatial data layer of Mangrove distribution derived through Landsat image classification. UK: UNEPWCMC, Cambridge; 2016. 
12. United States Agency for International Development (USAID) Biodiversity and Carbon Potentials of a Nigerian Forest Reserve: Insights from the Niger Basin. UK: Chemonics International Inc; 2008:7-11.

13. Omogoriola HO, Williams AB, Ukaonu SC, et al. Survey, Biodiversity, and Impacts of Economic Activities on Mangroves Ecosystem in Eastern Part of Lagos Lagoon, Nigeria. Nature and Science. 2012;10(10):30-34.

14. Olowokudejo JD, Oyebanji OO. Floral diversity of the littoral vegetation of Southeastern Nigeria. International Journal of Biodiversity and Conservation. 2016;8(12):320-333.

15. Tomlinson PB. The Botany of Mangroves. $7^{\text {th }}$ edition. UK: Cambridge University Press; 1986.

16. Emily Corcoran, Corinna Ravilious, Mike Skuja. Mangroves of Western and Central Africa. I UNEP-WCMC. UK: UNEPWCMC; 2007.

17. Abere SA, Ekeke BA. The Nigerian Mangrove and Wildlife Development. Mediterranean journal of social science. 2011;2(7):107-116.

18. Ukpong IE. Mangrove Soils of the Creek Town, Calabar River Swamp, South Eastern Nigeria. Journal of International Society for Tropical Ecology. 1995;36(1):103-115.

19. Ogar DA, Asuk SA, Umanah IE. Forest Cover Change in Stubb's Creek Forest Reserve Akwa Ibom State, Nigeria. Applied Tropical Agriculture. 2015;21(2):183-189.

20. Okpiliya FI, Effiong EB, Imoke E, et al. Mangrove Forest Ecosystem Utilization and Depletion: Implication for Occupational Changes in Calabar South, Nigeria. European Journal of Sustainable Development. 2013;2(1):149-162.

21. Agbagwa IO, Ekeke C. Structure and Phytodiversity of Freshwater Swamp Forest in Oil-rich Bonney, Rivers State, Nigeria. Research Journal of Forestry. 2011;5:66-77.
22. Olorunlana FA. State of the Environment in the Niger Delta Area of Ondo State. Portugal: Proceedings of 1st Annual International Interdisciplinary Conference (AIIC); 2013:24-26.

23. Dunn RM, Otu D. Recent Approaches to Participatory Forest Resource Assessment. In: J Carter editor. London: Overseas Development Institute (ODI); 1996;57-79.

24. Razavi SM, Mattaji A, Rahmani R, et al. The Assessment of Plant Species Importance Value (SIV) in Beech (Fagus orientalis) Forests of Iran (A Case study: Nav District 2 of Asalem, Guilan Province). Intl Res J Appl Basic Sci. 2012;3(2):433-439.

25. Iwara AI, Deekor TN, Njar GN. Effect of farming activities on tree diversity, density and community structure in Agoi-Ekpo, Cross River State Nigeria. Nova Journal of Engineering and Applied Sciences. 2014;2(2):1-7.

26. Sanwo SK, Ige PO, Sosanya OS, et al. Tree Species Diversity and Forest Stand Dynamics in a Tropical Rainforest in Southern Nigeria. Malays Appl Biol. 2015;44(2):65-73.

27. Rosenzweig ML. Species Diversity in Space and Time. Cambridge: Cambridge University Press. 1995.

28. Whitmore TC. An Introduction to Tropical Rain Forests. $2^{\text {nd }}$ edition. Oxford: Oxford University Press; 1998:296.

29. Waide RB, Willig MR, Steiner CF, et al. The Relationship between Productivity and Species Richness. Annu Rev Ecol Syst. 1999;30:257300 .

30. Condit R, Hubbell SP, Foster RB. Mortality rates of 205 neotropical tree and shrub species and the impact of a severe drought. Ecological monographs. 1995;65(4):419-439. 